\title{
Investigating the Civil Liability of Tobacco' Propagandists in Iran: A Comparative Viewpoint toward American Legal System
}

\author{
Mohsen Safari ${ }^{1}$ \& Mehdi Safarian ${ }^{2}$ \\ ${ }^{1}$ Islamic and Law department, Faculty of Law \& Political Science, University of Tehran, Iran \\ ${ }^{2}$ Department of Law, Kish International Campus, University of Tehran, Kish, Iran \\ Correspondence: Mehdi Safarian, PhD student of Kish International Campus, Department of Law, Kish \\ International Campus, University of Tehran, Kish, Iran. E-mail: safarian.mehdi@ut.ac.ir
}

\author{
Received: September 4, 2016 Accepted: October 2, 2016 Online Published: December 29, 2016 \\ doi:10.5539/jpl.v10n1p210 URL: http://dx.doi.org/10.5539/jpl.v10n1p210
}

\begin{abstract}
One of the most important signs of a dynamic economy is commercial advertisement and presentation of products. Advertisement in fact, helps consumers to become aware of various goods and make a move for buying those needed. However, it should be noted here that whatever intended to be advertised should not be harmful to people and society; advertisement, if restricted to goods and products, would not lead to so much negative criticism, but in reality it embraces selling of imaginations, dreams, and idealistic life styles. Therefore wrong components can lead to a liability. On the other hand advertisement is increasingly related to society's health. This study aims at investigating propagandists' liability in light of the theories of civil liability. Therefore, in facing the fundamentals of civil liability in this area, the theories of guilt and strict liability are able to be examined. Studied the running rules of national and transnational domain, however, the approach considered as the basis of civil liability in this area is the theory of guilt. In the legal system of Iran, according to what was pointed out and considering the exclusive nature of tobacco, the guilt theory is ruling on the process and cycle of tobacco including production, distribution, and promotion. Considering American rules have also revealed that some rules suggest the fact that the theory of strict liability has executive capability in light of damage compensation, but the recent approach of American legislator has deviated from this standpoint and inclined toward the theory of guilt. In any case, the writer strives at investigating the position of damage compensation and fundamentals of advertisement liability, through explaining the ruling theories in this area.
\end{abstract}

Keywords: advertisement, tobacco, civil liability, guilt, strict liability

\section{Statement of Problem}

Recognition of fundamentals of propagandists' civil liability, especially in the domain of products, which itself traverses an uncommon boundary, is a challenge that involves legal rules too. Thus to investigate a vivid image of non- penal execution guarantee, its resources must be studied as well. In order to reach this goal, the liability fundamentals and resources must be examined according to the elements of civil liability and the position of loss or detriment compensation. Therefore, in the following, we examine the resources related to advertisements in both Iranian and American legal system, prior to analyzing the fundamentals of civil liability.

Investigating the fundamentals of civil liability resulted from advertisement, requires the recognition of various fundamentals and resources. The right of freedom of expression and information, in companion with the right of liberty in private life and protecting secrets, is limited. The precondition of economic activities such as advertisement, is not to make loss to others and if so, the guilty person is obliged to compensate it. The basis of liability for advertisement in the domain of tobacco, is the modern theory of guilt, meaning that exiting the common behavior and lack of intention would not remove the liability. The three elements of liability consist of injurious act, loss, and causality relationship; and of the most important proofs of promotional guilt in general would be sanctity violation, privacy violation, and commercial brand violation; if the propagandist commits any of these guilt, and other conditions (loss and causality relationship) also exist, it results in civil liability. Damage compensation is accomplished in two ways of financial and non-financial, and the most usual method of financial damage compensation is payment of money, and the non-financial methods_according to the type of guilt_ include the obligation of correction, responsiveness, removing the loss making effects, etc. The authority for investigating the civil liability claims of the propagandist is determined based on the kind of Propaganda 
Company which is private or Government Company. About the government propagandists such as media, the claims are primarily proposed in the Administrative Court of Justice, and after attaining the guilt, the case will be referred to the General Court in order for considering and issuing the sentence.

\section{Investigating Legal Resources in Confronting the Fundamental of Civil Liability in Advertisement}

\subsection{In Iran}

In order to study tobacco advertisement and the pertaining resources in Iran, we have to primarily explain general laws in this area. The first law to cite in support of this argument, is the law of civil liability. The basis of civil liability in this law has been set on guilt theory, based on the first article. According to this law what is going to be considered as the outcome of the advertisement nature in general, is the theory of guilt. Of other important laws generally considered on the issue of advertisement prohibition, is the law of fifth development planning. Number 37 of this law, in line with prevention of and confrontation with illnesses and factors harmful to health that have the most economical and social expenses, has predicted activities such as prohibiting the advertisement of harmful goods. Thus the job of identifying harmful goods has been undertaken to a committee under the responsibility of the Ministry of Public Health, Medical Care and Medical Education and the membership of the Ministry of Economy and Finance, the Ministry of Labor and Social Affairs, and the Ministry of Industry, Mines and Trade. This law has made strict liability, as the basis of liability, meaning that guilt proving from the consumer's side is not required, rather due to the law in case of advertising products and services harmful to health, the crime would be definite and the outcome of such a crime would be civil and penal execution guarantee.

What will be bearing in mind in the following, is the relationship between this law and the tobacco advertisement. Although the number 37 law of the Planning and Budget Organization is allocated to especial proofs, tobacco advertisement can be included in it too; since tobacco is naturally harmful to physical, mental, and economical health of the society. When advertisement of some products as fast foods is included in the limits of this article and is blamed by the law and following it the execution guarantee, therefore tobacco advertisement may as well be included in this law. However, this analysis will have proofs only when some votes could be presented in judicial procedure as well, under the support of this approach. This approach has obvious shortcomings, especially in a tobacco advertisement in Iran.

Other than general laws, there are some especial laws in this area explaining the prohibition of tobacco advertisement. For instance the prohibition law of utilization and distribution of cigarettes and other tobacco, ratified bill in 1997, and the master law of national controlling and struggling against tobacco, ratified the bill in 2007. In article 10 of this law, the legislator has focused on proofs of civil liability, other than attaining penal liability. Thus, this law can be viewed especially as a resource of civil liability of advertisement in tobacco products. The basis of liability in law generally and in the aforementioned article specially, is the theory of strict liability. The legislator explains in this article that: any kind of advertisement, direct or indirect, is prohibited. Therefore, in tobacco advertisement, the propagandist companies or individuals will be included in this law and its execution guarantee just as they begin the job of advertising.

In line with attaining civil liability based on the theory of strict liability, it should be noted that: using names and commercial brands of companies manufacturing tobacco for other goods_that is considered an advertisement for tobacco consumption_is prohibited; and sale and distribution of such products by authorized agents should not be representative of tobacco advertisement for the public. On the other hand bestowing any kind of tobacco product donation and support, financial or non-financial, of manufacturers, importers, and exporters that are considered the advertisement of such products, is prohibited; and import, production, distribution, and buying and selling any means of advertising tobacco, is prohibited. The recovered goods of advertisement will be prosecuted according to the regulations.

Determining the "execution guarantee" is of great importance in all legal systems, so that setting laws without considering liability to its violation, is one of the features of an inefficient legal system. Here what is meant by "Liability" is an individual's liability for violation of a legal rule, usually divided into two groups of civil liability and penal liability. The purpose of the current study is to examine the civil liability of tobacco propagandists in light of the running laws. It should be mentioned prior to the issue examination that tobacco exclusive in Iran, greatly affects the civil liability of such products' propagandists, since the outcome of the advertisement is achieving a sale market with making a profit as its main objective. Such a deal does not equal to profit, rather a possession with the government being its administrator. Such an interpretation is not a negation of the law, as will come in the following, various laws cover propagandists' liability. However the challenge here is the implementation of the law and the power to enforce it _what has no appearance in confronting the hegemony of 
prudence and benefit of jurisdiction. Basically, when governmental organs are not bound to the law, it would be impossible to make the citizens following the laws; since the legislators themselves are considered lawless so they cannot have supervision on law implementation.

\subsection{In America}

Tobacco products companies of America spend significant budgets for their advertisement. For instance, according to the Federal Trade Commission of America, during 1999, cigarette manufactures of this country spent 8.24 milliard dollars for the promotion of their products. It should be noticed here that such great value of tobacco advertisement is performed in conditions when in most of the countries many restrictions exists for cigarette advertisement, and tobacco companies struggle to perform such activities through more indirect ways (Kiani, 2011, P:3).

One of the most important laws of prohibiting tobacco advertisement, recently legislated by the Food and Drug Administration of America is "the plan of systematized use of electronic cigarette" which was implemented in all cities of America since Tuesday 29 April 2013. This plan asks the manufacturers of electronic cigarettes, whose products are well received, especially by the youth, to obtain this organization's legal authorization prior to delivering their products to the market.

Thomas Fierly, New York's ex-commissar of health, argues that "what matters here is continuous supporting of consumers and alerting them before they completely become aware of the real effects of these cigarettes" (New York Times, 2013 , p.5). This was the first move in America, for legitimizing the sale advertisement prohibitions and systematic use of tobacco. According to this law and to the requirement of propagandists to obtain authorization in the previously mentioned laws, the theory of guilt is what makes the basis of liability. The nature of such claim must be investigated within indices and components of this law. Allusion of this rule to the plan of prohibiting the free distribution of promotional samples, the obligation to insertion of the used materials on the products' covers, and alerting the threats of using such uncommon cigarettes, leads to attaining a guilt to the person in charge of recognizing promotion companies; otherwise it is hardly possible to recognize a liability resultant of free advertisement of such products.

If we intend to examine judicial procedure of America in prosecuting tobacco in terms of resources, we must claim that the history of making cases against companies manufacturing tobacco and as its consequence the promotional companies, outreaches a half century. However, what is under consideration in America's Legal system, is November 1998 when striving for the tobacco began to expand. This initiation provided the Attorney General of 46 states with a lawsuit against the biggest tobacco. The result of this judicial strives was an agreement on settling the dispute in cases under consideration. The first part of this agreement pointed out the fundamentals of advertisement to tobacco companies. It was mentioned there that tobacco should not carry on with particular ways of advertising such products, especially initiating campaigns that systematize advertisements; since tobacco were distributed extensively for the children and teenagers.

A case of 1990, with documents divulged on the addictive feature of tobacco, leaded to the jury's vote for paying damages of 51.5 million dollars to a smoker suffering from cancer. (Silber, 1995, pp. 52-53.).Although this vote was issued to the Morris Manufacturer Company, soon it turned into a basis for the prohibition and restriction of advertisement. According to this perception, it should be noted that in laws legislated after such events, limitations as no advertisement in school neighborhood, advertisement with alert mark, and obligation to negligence on the job of advertisement, would identify the propagandist in tobacco as the guilty person.

Anyway, other than the law and judicial procedure, the resources of civil liability for tobacco in America can be found in international documents as well_ a resource that Iran's legal system follows it too. Therefore, in the following we will point out to some of these documents and examine the nature of their civil liability (Breyer, 2002, PP: 120-135).

\section{Fundamentals of Tobacco Advertisement Prohibition in International Convention on Tobacco Control}

In 2003, most countries having membership of international convention on tobacco control, which holds conferences under the supervision of World Health Organization, signed a contract bearing this content:

1) Although tobacco advertisement prohibition has been running in advanced nations since 1960, the unfortunately indirect advertisement was common having increasing effects on individuals, so that tobacco consumption is introduced as resulting in maturity and self-confidence.

2) Warnings imprinted on cigarette packs must be extended, e.g. in Brazil $30 \%$ of the cigarette pack must be consumption alerted in local language. Such an extension in America and Canada must be 50\% of the front and back of the cigarette pack. 
3) Besides, imprinted words have images for illiterate or semi-literate people.

4) The government's duty is making policies to give required instructions; since the age range of cigarette addiction has reached to 10 and 11, the necessary instructions be taught in houses and schools as well. Tobacco in many countries has turned into a lesson to be taught in age of 10 , since regardless of the cigarette quitting benefits, it has less advantages over the age of 40 . Thus the school is considered as the target society since students are inclined to cigarette due to their sense of maturity. In America, having an official permit of selling cigarette is necessary for every single store, the minimum age of buying cigarette has changed in 21 , and cigarette quitting is supported.

Similarly, this agreement is called for experiment, measurement, and setting the contents and materials of tobacco productions. The effects of the legislative branch, executive branch, and official system on propagandists and manufacturers' requirements for legal moves are also examined in this convention, in order to reveal the toxicity of such products generally further to their imports (Ruth Roemer, et al., 2005, pp: 936-938).

In1945, with the approval of the general assembly of the United Nations organization, WHO (World Health Organization) was established and its constitution was approved in 1946, and the substance of this law was implemented since 7 April 1948 titled further as the World Health Day. WHO is in charge of direction and coordination of world peoples' health within a UNO frame (Griffiths, 2009, P: 15).

In order to struggle against tobacco consumption epidemy, WHO has introduced the MPOWER set, consisting of six policies for controlling tobacco consumption (Young, 2005, p: 87). This set can take control of tobacco consumption and prevent from millions of deaths because of tobacco consumption.

This set of policies includes:

1) Monitor tobacco use and prevention policies

2) Protect people from tobacco smoke

3) Offer help to quit tobacco use

4) Warn about the dangers of tobacco

5) Enforce bans on tobacco advertising, promotion, and sponsorship

6) Raise taxes on tobacco

This organization has set its fifth policy on the basis of limiting and preventing advertisements. The fact is that international documents are compulsory to the extent that they are in line with internal regulations. This means that when internal regulations are approved contrary to the international documents, their sovereignty and the common law have the power to stop from executing law based on the approved international documents.

\section{Islamic Jurisprudences' Perspectives on Civil Liability of Tobacco Advertisement}

Islam, as a complete school and the last Devine religion, have not desisted from explaining anything related to human beings' guiding, and in the area of trade and business has commanded and forbidden something with emphasis, meaning that it has considered them a religious duty or unlawful, and has introduced some topics as rituals of the trade i.e. recommended matters. Islamic jurists believing in advertisement permission argue that: it is religiously correct to working in the industry of business advertisement and there is no prevention for actual people and body corporate to earn money through producing or broadcasting commercials about others' goods or services. There is not any prevention of such activities, rather their permission can be derived from some hadiths. For instance, in a hadith by Imam Ali (peace be upon him), he has commanded to dealers:

"با معاشر السماسره اقلّو الأيمان فانها منفقه للسّلّعه و مدحقه للربح" (Imam Khomeini, 1994, 1st vol ,P:5).

The word "السماسره", the plural word for the English "dealer", is originally a Farsi word meaning a mediator between the seller and buyer, who tries in favor of one part of the deal in order to encourage the other part (Ameli, 1982, P: 284).

Thereafter, in the Quran verse under discussion, it is said: "Yet whenever they see some business or some sport, they flock towards it and leave you standing there [alone]. SAY: Whatever God has is better than any sport or business. God is the best provider". Thus Islamic jurists agreed to permission, believe that according to the aforementioned hadiths no prevention is made for the merchandises' advertisement. It is only recommended that avoid telling lies and futile works; and about the tobacco, since there is a hadith confirming the filth of such materials, therefore advertising such products is permissible provided that it does not lead to quitting a religious duty such as God and his Prophet's Commandments. 
Islamic jurists believing in the prohibition of tobacco advertisement argue that although commercials per se are not being forbidden, we must be attentive that proof of one part of the deal not turn into a forbidden one, so if another command is issued. As an example, swearing so many oaths (true!) or applying forbidden music instruments or fun and games in commercials will make them religiously prohibited_as it was revealed in previous hadiths.

Likewise, commercial advertisement for selling filth goods such as wine or pork, is religiously prohibited. Moreover, advertising goods which have unlawful uses or which have not logical benefits, such as tobacco, or advertisement involved with unlawful ways (e.g. distributing misleading topics, deception, telling lies, gambling, etc.), are religiously prohibited. Tobacco advertisement is sometimes considered "companion in crime". The sanctity of "companion in crime" is one of the famous religious laws that is proved based on religious reasons and has been implemented in many cases (Tabatabaei, 1982, vol19 .P: 274).

In another hadith, our Holy Prophet (peace be upon him) has commanded:" people's job is considered pure on the condition that four things exist: do not find fault with what they buy, do not praise what they sell, do not deceive the other side, and do not swear an oath during the deal" (Ameli, op. cit). Therefore, tobacco advertisement is one of the proofs of deceiving buyers, since making them indifferent about the harms of tobacco thus it is religiously prohibited (Imam Khomeini, 1994, P: 5). According to the reasons of the believers for permission or prohibition of advertising tobacco, it can be concluded that believers' reasons for prohibition from the religious viewpoint enjoy more solidity, and due to the fact that Iran's legislator has also banned tobacco advertisement, it is crystal clear that it has accepted believers' reasons for prohibition.

\section{Elements of Civil Liability Derived from Tobacco Advertisement and Damage Compensation in the Legal System of Iran and America}

\subsection{Loss}

Damage is considered as one of the main elements of civil liability. In other words civil liability has the personal and social appearance and has criteria that based on them guilt is separated from its ethical concept and is always accompanied by the existence of loss. However, ethical liability means disgrace, compensation, and having a sense of guilt, and mostly has personal aspect, and the meaning of such liability has never been apart from guilt. Whenever the damage is occurred due to a carelessness that is negligible according to convention, and its compensation lead to destitution and poverty of the one who caused the loss, this law apparently confirms the integration of civil and ethical liability.

It must be accepted that to the extent that guilt is intensified, the liability will be extended. On the other hand, the unjust damage must be able to be compensated; in this respect it must be indisputable, direct, remaining, and predictable (Katuzian, 2007, PP: 242-243).

The goal of civil liability laws is damage compensation, in other words, there should be a damage in order to build a liability for its compensation. Thus, loss must be considered as the main element of civil liability.

In the first and second article of civil liability law, the existence of loss _ financial or nonfinancial _ is eligible for damage compensation. Based on the discussed articles, propagandists and owners of advertisement companies and jobs, cannot bring damage to others, if so they are responsible.

In Iran, the term professional manufacturers, is applied to those who are aware of merchandises' damages. That is advertisement companies know well, which goods are appropriate for distribution and advertisement, meaning that they are completely informed about their damages (financial, moral, and physical). Therefore, just as the damage is proved and its relationship with loss is attained, the manufacturers or distributors' responsibility is put in the limelight. This way of investigation in judicial procedure is practiced in Iran today. Based on this explanation if we refer to current laws of advertisement prohibition and use general rules accepted through principles of law and Islamic jurisprudence and also the civil liability law, we can draw inferences that loss can be considered as the basis of liability for those active in tobacco advertisements.

As it was discussed, two laws for prohibiting use and distribution of cigarettes and other tobacco_ratified in 1997_ and the master law of controlling and national striving against tobacco_ratified in 2007_ have typically confirmed the prohibition of advertisement in the area of tobacco. This article has obviously put tobacco propagandists in charge. Thus, based on the general obligation that legislator has practiced it and also the total prohibition of direct and indirect advertisement by people, strict liability can be considered as the theory ruling such prohibition. In strict liability, as it is obvious, the claim of liability focuses on the product itself, not on a special individual and here tobacco propagandist.

Following this procedure in America, we can evaluate the three elements mentioned (B. Dobbs, 1993, PP: 
441-445). In America's law the capability of loss prediction is studied as a sample in common law and under the topic of "loss distance". Loss distance is an impediment and loss nearness is the precondition of its capability to be compensated; by loss distance it is meant that whether making damage is appeared common "distant" or not, in the views of the two sides, and this is the common predictability which is the topic of our discussion (Joossens, 1997, P: 10). In other words, in America's legal system, the necessity of predicting a loss in out of the deal requirements is based on two different perspectives including:

1) Distance of loss; according to deal liability in out of the deal requirement the precondition is that the loss does not go far from the action. In order to determine the distance or nearness of the loss, it should be examined whether the harmful result was one of the predictable results of the act or not (case: Repolemis, 1921).

2) From the eye of the guilt concept; a viewpoint that introduces and analyzes the law of loss predictability, and is accepted and implemented in America. From this viewpoint, the action is not responsible for the results which could not be predicted at the time of the incidence. The basis of determining predictable losses is the same as the basis of guilt (case: Pals grafv. long 1sland Railroad, 1928).

Thus, in the legal system of America, what does exist in confronting the loss and predicts the individuals' this context the propagandists _ liability, is the theory of guilt, since only the predictable losses could be demanded. Therefore, recognition of propagandist's liability does exist when an action is performed based on the existence of loss, so in this context the loss can be related to the knowledge of the danger resulted from the action. It is concluded that the extent to which the danger of a product creates the necessity of commitment toward presenting information about it, is an important issue. Where the nature of a product is so that it may result in little damage to the buyer, or where the nature of a product is so that it may cause a little damage to the buyer, is there any commitment to presenting information? Or, since the resulted damage is of little importance to the existence of danger is not considered as the causes of necessity in providing information. One of the America's courts of law, has announced that in cases where the product danger may result in somehow limited damage to the buyer, since the use of the product may result in little damages for the buyer, the commitment to information provision is not influenced and the seller is obliged to provide the buyer with the necessary information pertaining to the product. It seems that in this case we must refer to the common law judgement (American Jurisprudence, "Product Liability", 1997, p: 55). For instance a hammer is not usually considered dangerous for it can harm a person's thumb. However, merchandises such as tobacco and drug are apparently products which are usually considered dangerous. The seller is obliged to provide the buyer with the necessary information about them. Otherwise the outcome is the loss which is made due to lack of information provided (Bacache, 2007, p: 47).

\subsection{The Injurious Act}

In the past, the injurious act was merely sufficient to obligate the doer to damage compensation, so that considering the doers' inner motives was not necessary (Federal Trade Commission, 2016, p: 56). In tobacco advertisement, merely inflicting a damage to the consumer, was immediately creating a liability for the seller as well. Gradually this idea was strengthened that the merely infliction of damage cannot be a reason for demanding damage compensation. In fact the individual must have performed an action to ethically blame them for it. The injurious act must be accompanied with the guilt too; thus the guilt theory was considered as the traditional basis of liability, meaning that: turning from accepting the strict liability to accepting the liability based on the guilt (Lecours, et al., 2012, PP: 191-196).

Anyway the injurious act is one of the elements of the civil liability that can be effective in confronting with the propagandist. Since the nature of such an element is the existence of an act which leads to and represents the first element i.e. the loss. Therefore, another element of a civil liability would be the harmful act; such an act must be considered abnormal and no authorization be envisioned for it. Injurious act may be an act or leaving an act (Dalvand, 2007, P: 21).

In the first article of civil liability law, it has referred to the term "without legal authorization", meaning that if the act is performed with the legal authorization the individual is not responsible for its damage. In civil liability it is conditioned that the injurious act is not being unlawful, and this harmful act is represented in guilt element; in order for an individual to commit neglect and imprudence, the loss must be predictable and attainable. Some have interpreted the guilt as the subjective act; subjective act means violating the common behavior, and its personal element the predictability of loss.

Propagandists, manufacturers, and distributors are not directly involved in causing customers to suffer from a loss (Krawiec, 2005, p: 1825). They cause losses through providing the grounds or preliminaries for harmful incidents. Thus, if the reason is an industrial product, the manufacturers are responsible. However, this is true for 
a product with totally common nature. But the question is that, is it true for tobacco as well and is the plaintiff obliged to verify the loss is from the propagandist? The fact is that there is no procedure in Iran to provide a solid answer to this question. However, as it was mentioned in previous parts, what is inferred from the legislator's purports and can traverse the logical procedure too, is strict responsibility. When the tobacco propagandist, regardless of legal prohibition, claim that he was not informed about his advertisement's loss, if the plaintiff has suffered from its loss, he has to verify it. This is not impossible, but very difficult and could be a reason for renunciation from the claim.

In America's legal system, in the past, the victims of crime and faults and also their relatives had not the opportunity to demand the damages resulted from the harmful acts; therefore the courts had not problems of calculating such damages. However, in the beginning of the 19th century, in most states of America, laws founded to provide the possibility of demanding damage compensation (B. Dobbs, 1993, p: 443). It was then that American jurists decided to find ways in which such damages could be compensated optimally. Therefore, as times went on, two systems of compensating the damages were resulted from harmful acts were developed in the legal system of America; one was a system based on regulations compiled by independent legislative organizations, and the other was a legal system of civil liability resulted from faults with the latter having more precedence.

Therefore, America's courts, following the same laws, pay such damage compensations to the victims, however the related rules applied by each state in separate judicial areas are different from each other. It should be noted that today in America's judicial system, a claim can be proposed against the manufacturer of the defective product, based on three elements of guilt, violation of implied warranty, and strict liability of harmful act. However, citing a document in support of strict liability and its interpretation is dependent on the law ruling in the state. For instance, in California the judges even ignore the dangerous aspect of the product and exempt the plaintiff from verifying the defect; such a trend is not common out of California, where the judges deem it necessary, based on the plan, the merchandise is uncommonly dangerous (B. Dobbs, op. cit).

\subsection{The Causality Relationship}

In order for an incidence to be considered as the cause, it should have the preconditions necessary for the loss realization, meaning that it be attained that there would be no loss without it (Katuzian, 2011, P: 186). The necessity for building a causative relationship between the injurious act and the loss is important in that sometimes various reasons are involved in causing loss. This was mattered and considered as a criterion in a tobacco advertisement (Sheroow, 2010, P: 57).

Focusing on the current rules of America's law, it seems that for accessing a basis, the strict liability is required. Such a liability is representative of a liability which is built on the judgement of law and based on prudence and expediency, and does not follow general rules of civil liability, therefore it is called typical liability. The goal of such liability is to imposing the guarantee to the outcome of the act rather than its quality. In other words, regardless of the propagandists' guilt or lack of guilt in his act (manufacturing and delivering harmful merchandise) he is responsible for the losses caused by his merchandise.

It should be noticed in the process of accepting the strict liability in America's tobacco, that after a case called "Greenman", Supreme Court of California generalized strict liability to all components including manufacturer, propagandist, and also defective products. In 1969 strict liability included only those incurred losses directly from the deficit merchandises. Ever since most of the judicial areas, such as Trainor the Judge, reasoned that regulations ruling the strict liability will be taken into consideration in Scola Greenman cases. This was a turning point in America's legal life to pay attention to strict liability of manufacturers, propagandists, and even retailers.

In fact, this is not the end of judicial procedure to consider a strict liability to the propagandists of internal products in light of it, but some other claims and legal cases have paved the way in favor of propagandists and have released them of the challenge of strict liability. For clarifying the issue, it should be noted that: a court in America has commanded a sentence that tobacco manufacturers cannot be obligated to use cautionary images on cigarette packs. Gennis Rodgers Brown the Judge has argued that imprinting such images is a way that makes customers "ashamed" to lead them toward quitting cigarette. Due to the fact that based on the researches in America, imprinting cautionary images on cigarette packs, encourages individuals to quit cigarette, the organization of FDA in America has obliged cigarette manufacturing factories to imprint cautionary images about the damages of consuming tobacco on cigarette packs. Following this law has established a basic procedure which _in the body of civil liability_ moves away from. On the other hand the tobacco industry strived against the government's attempts to enlarge the size of cautionary images on cigarette packs. Tobacco companies in America filed a complaint against the America's FDA command of imprinting graphic images on 
cigarette packs, and an appellate court suspended the execution of this sentence due to its conflict with the first amendment to America's Constitution i.e. freedom of expression.

Consequently, federal government of America puts aside legal strive in these issues against these companies in March, 2013 and announced that there is no obligation for imprinting graphic images on cigarette packs, and decided not to refer the case to the Supreme Court of America; instead it was arranged that new cautionary images from tobacco manufacturing companies be imprinted and advertised on tobacco packs (Shafa online news and information database, news code: 28940, 2014).

This approach not only freed the tobacco propagandists, but also in making damage compensation cases, only those claims of plaintiffs revolving around building desire and motivation and further the tobacco consumption, were taken into consideration. In fact, in these cases, America's federal government and tobacco manufacturing companies have reached to a kind if agreement. Yet based on the appellate court's vote, the government's obligation for imprinting graphic images on cigarette packs and striving against positive advertisements of tobacco, has known as being in opposition to the first amendment of America's constitution on freedom of expression.

\section{Conclusion}

In order to observe the hygienic and health requirements of citizens', different laws have prohibited some advertisements. This prohibition encompasses various merchandises such as foodstuffs, drugs, cosmetic and hygienic products, tobacco, etc. Such laws, not only build civil liability but also suggest a kind of penal responsibility. Due to the focus of the current study on civil liability, it must be admitted that the goal of civil liability is damage compensation rather than punishing the criminal. Therefore, in order to reach out civil liability through laws based on the prohibition of tobacco, the common law criterion must be adopted; since legal criterion only includes generalities which can be accepted and combined with civil liability laws. Anyhow, based on what is being discussed, there exists regulations on advertisement prohibition in both Iran and America. Such regulations in Iran, have adopted an approach which reminds us of the theory of guilt. However, focusing on the literature of regulations it should be claimed that the theory accepted in liability of tobacco propagandist is the theory of strict liability. In America's law, however the state is different. Since tobacco does not have an exclusive nature separated from the government and the regulations are more probable to be implemented. Although in this area, great business cartels and trusts rush on implementing the laws, these proofs can be investigated in judicial procedure of America. What comes to the minds while studying and reviewing the history of America in a tobacco advertisement, is strict liability; however, considering the regulations set by judges, the outcome would be the guilt theory according to which the loss and the injurious act and the causality relationship must be attained.

\section{References}

Ameli, H. (1982). vasael alshieh. Tehran, maktab eslami publication. P: 284.

American Jurisprudence. (1997). Product Liability (Vol. 63, 2nd ed.). Jurisprudence Publisher. America, P: 5.

B. Dobbs, D. (1993). Law of Remedies; damages, equity, restitution (2nd ed.). West Pub.Co St. Paul, Minnesota, USA. PP: 441-445.

Bacache, G. (2007). Droit civil. les obligations. La responsabilite civile extracont ractuelle. Economica, france, p: 47.

Breyer, S. (2002). Administrative Law and Regulatory Policy (5th ed.). Aspen publishers Inc., USA. PP: 120-135.

Dalvand, F. (2007). Division of civil liability (1st ed.). Isfahan, Dadyar publication. P: 21.

Federal Trade Commission. (2016). Federal Trade Commission Cigarette Report for 2013. Washington: Federal Trade Commission. P: 55.

Griffiths, M. (2011). Encyclopedia of International Relationships and World Policy (2nd ed.). translation: Tayyeb, A. Tehran, Ney publications. P: 15.

Joossens, L. (1997). The effectiveness of banning advertising for tobacco products. Brussels, International Union against Cancer. P: 10.

Katuzian, N. (2007). Forcible Guarantee_Civil liability_Usurpation \& Reclamation (8th ed.). Tehran. Tehran university publications. pp: 242-243.

Katuzian, N. (2011). Liability of Manufacturing Defect (3rd ed.). Tehran UniversiTy, p: 186. 
Khomeini, I. (1994a). Makaseb Al-Hormah (1st ed., Vol 1). The institute for compilation and publication of Imam Khomeini's works. Tehran. P: 5.

Khomeini, I. (1994b). Islamic Laws \& Regulations (1st ed.). Islamic Publication Center. Gom Seminary, P: 5.

Kiani, M. (2011). American Pack. (Newspaper) Topic code: 2996, Tehran, P: 3.

Krawiec, K. D., \& Zeiler, K. (2005). Common Law Disclosure Duties and the Sin of Omission. Virginia Law Review, 91(8), 1825.

Lecours, N., Almeida, G. E. G., Abdallah, J. M., \& Novotny, T. E. (2012). Environmental health impacts of tobacco farming: A review of the literature. Tob. Control, pp: 191-196. https://doi.org/10.1136/tobaccocontrol-2011-050318

New York Times (News Paper). (2013, January 30). As U.S., law about electoronic sigaret, p.5.

Roemer, R., Taylor, A., \& Lariviere, J. (2005). Origins of the WHO FrameworkConvention on Tobacco Control. American Journal of Public Health, 95(6), 936-938. https://doi.org/10.2105/AJPH.2003.025908

Shafa online news and information database. (2014, July, 19). reviewing the regulations of imprinting cautionary images on cigarette packs.

Sheroow, V. (2010). Product Liability. Chelsea hose Publisher. P: 57.

Silber, N. I. (1995). Test and protest. New York: Holmes \& Meier: Holmes and Meier. PP: 52-53

Tabatabaei, S. M. H. (1982). Tafsir al-Mizan. Islamic Publication Center. Qom Seminary. Bita. p: 274.

Young, T. K. (2005). Population Health: Concepts and Methods. Oxford University Press, p: 58.

\section{Copyrights}

Copyright for this article is retained by the author(s), with first publication rights granted to the journal.

This is an open-access article distributed under the terms and conditions of the Creative Commons Attribution license (http://creativecommons.org/licenses/by/4.0/). 